\title{
Window on the World
}

This issue of Window on the World introduces a selection of key organizations engaged in promoting alternative development paradigms. Through research activism, campaigns and policy work, they are revealing the level of discontent with the current development model. By engaging in a process of social and economic transformation, they are seeking to tackle negative global development patterns and to address the issue of how participatory democracy can function in today's fractured world.

\section{Association for Progressive Communication (APC)}

www.apc.org

APC is an international network of civil society organizations dedicated to empowering and supporting groups and individuals working for peace, human rights, development and protection of the environment, through the strategic use of information and communication technologies (ICTs), including the Internet. APC's members were often the first providers of Internet in their countries. Today, they continue to pioneer practical and relevant uses of ICTs for civil society, especially in developing countries. APC is an international facilitator of civil society's engagement with ICTs and related concerns, in both policy and practice.

\section{The Corner House}

www.thecornerhouse.org.uk

The Corner House is a UK-based NGO that aims to support the growth of a vibrant, democratic, equitable and non-discriminatory civil society in which communities have control over the resources and decisions which affect their lives and means of livelihood, and have the right to define themselves rather than being defined by others. As part of its solidarity work, The Corner House carries out analysis, research and advocacy with the aim of linking issues, of stimulating informed discussion and strategic thought on critical environmental and social concerns, and of encouraging broad alliances to tackle them.

\section{DAWN (Development Alternatives with Women for a New Era)}

www.dawn.org.fj

DAWN is a network of women scholars and activists from the economic South who engage in feminist research and analysis of the global environment and are committed to working for economic justice, gender justice and democracy. DAWN works globally and regionally in Africa, Asia, the Caribbean, Latin America and the Pacific on the themes of the Political Economy of Globalization; Political Restructuring and Social Transformation; Sustainable Livelihoods; and Sexual and Reproductive Health and Rights, in partnership with other global NGOs and networks. 


\section{The Development GAP (Development Group for Alternative Policies)}

www.developmentgap.org

Based in Washington DC, Development GAP is a centre for analysis, advocacy and action dedicated to creating synergy between policy and development alternatives of the Global South and the work of policymakers in the North. It plays a mediating role in order to close the wide gap that exists between the two. It also networks with environmentalists, development workers and others involved in issues of social justice.

\section{El Taller}

www.eltaller.org

El Taller is an international network of NGOs and social movements that aims to strengthen civil society and enhance South-North and SouthSouth exchange and dialogue across diverse cultures and civilizations. It seeks non-violent means of social transformation, and searches for alternatives to the dominant discourses on human rights, development, security. El Taller attempts to be a space in which voices from civil society and from diverse cultures can be heard; to seek and share thinking, experiences and values, and to struggle for a world in which peace, respect for human rights and sustainable human development are the norms.

\section{Focus on the Global South}

www.focusweb.org

One of the leading centres lobbying against corporate-driven globalization, Focus on the Global South is a research, analysis and advocacy organization based in Thailand. Its main aim is to promote a deeper and more systematic link between grassroots and 'macro' level development strategies and paradigms. Focus carries out work in five thematic areas: peace and security; trade and financial liberalization; state, market and civil society; international and regional financial institutions; cultural responses to globalization. It publishes papers, books and articles as well as

128 the e-bulletin 'Focus on Trade'.

\section{Global Policy Network}

www.globalpolicynetworkorg

This network consists of policy and research institutions and trade union movements in both North and South. It aims to facilitate the investigation and dissemination of information about the state of working people in the global economy in order to ensure a more equitable and sustainable transnational economic order.

\section{Greenpeace}

www.greenpeace.org/internationalen/ Greenpeace aims to promote open, informed debate about society's environmental choices. It uses research, lobbying, and quiet diplomacy to pursue its goals, as well as high-profile, non-violent conflict to raise the level and quality of public debate. Greenpeace has been campaigning against environmental degradation since 1971 when a small boat of volunteers and journalists sailed into Amchitka, North of Alaska, where the US Government was conducting underground nuclear tests. This tradition of 'bearing witness' in a non-violent manner continues, and Greenpeace's ships are an important part of the organization's campaign work.

\section{Inter-Press Service}

www.ips.org

IPS is a news service for journalists with a website that provides news features, analysis and expert commentaries on the events and global processes affecting the economic, social and political development of peoples and nations, especially in the South. IPS focuses attention on the countries of the South and on the marginalized in the North, and goes behind the scenes to examine and analyse what is happening, so that people can begin to understand the complex processes that lie behind day-today events. Inter Press Service is supported by a network of journalists in more than 100 countries.

\section{Panos}

www.panos.org.uk

The principle aims of the Panos Institute are to illuminate and provide insights from developing countries into issues facing us globally and to sti- 


\section{Window on the World}

mulate informed, enlightened discussion around such issues. Panos works to inform journalists and to make the complex issues facing developing countries accessible and understandable, to provide information that people can trust, and to open up opportunities for different perspectives to be heard. Panos was simultaneously founded in London, Paris and Washington in 1986 and now has offices also in Addis Ababa, Bamako, Dakar, Kampala, Kathmandu, Lusaka, New Delhi.

\section{People-Centered Development Forum}

www.pcdf.org

Rooted in the struggle for economic justice for all people, the PCDF works in cooperation with civil society groups around the world to articulate and tell a story that exposes the causes of our collective crisis and points to the possibility of creating a post-corporate, post-capitalist world of living democracies, mindful market economies, and authentic cultures. PCDF's founding director is David Korten, author of the influential books Getting to the Twenty-first Century: Voluntary action and the global agenda (1990) and When Corporations Rule the World (1995).

\section{Third World Network}

www.twnside.org.sg

The Third World Network is an independent nonprofit international network of organizations and individuals involved in issues relating to development, the Third World and North-South issues. TWN conducts research on economic, social and environmental issues pertaining to the South; publishes books and magazines; organizes and participates in seminars; and provides a platform representing broadly Southern interests and perspectives at international meetings such as the UN conferences and processes. It publishes the daily SUNS (South-North Development Monitor) bulletin, the fortnightly Third World Economics and the monthly Third World Resurgence, as well as a series of Third World Network Features and books on environment and economic issues. TWN's international secretariat is based in Pe- nang, Malaysia and it has offices in Accra, Delhi, Geneva and Montevideo.

\section{Transnational Institute}

www.tni.org

The Transnational Institute was founded in 1974 as a worldwide fellowship of committed scholaractivists. It was one of the first research institutes established to be transnational in name, composition, orientation and focus. In the spirit of public scholarship, and aligned to no political party, TNI seeks to create and promote international cooperation in analysing and finding possible solutions to such global problems as militarism and conflict, poverty and marginalization, social injustice and environmental degradation.

\section{Women's International Coalition for Economic Justice}

www.wicej.addr.com

WICEJ is an international coalition representing organizations in all regions of the globe, which seeks to bring a stronger economic analysis to women's issues and a stronger gender analysis to social and economic issues in the international arena. It works to link gender with macro-economic policy in international inter-governmental policymaking arenas, from a human-rights perspective. WICEJ seeks to bring local perspectives on gender and economic issues to the international arena, and conversely, to bring shared analysis from the international arena back to our regions and national communities.

\section{World Forum for Alternatives}

www.forum-alternatives.net

The World Forum for Alternatives (WFA) is an international network of research centres and militant intellectuals from the South and the North. Created in 1997 it aims to support the convergence process of social movements, as well as the development of alternatives that are democratic, pluralistic and sustainable. The WFA considers that the combined action of citizen movements, their demands and the socio-economic and political alter- 


\section{Development 47(1): Window on the World}

natives that they represent constitute the foundations of a more genuine democracy of the world system and the embryo of a just and sustainable model of society.

\section{World Social Forum}

www.forumsocialmundial.org.br

Since 2001, the World Social Forum process has questioned the rules of investment and governance dictated by the World Economic Forum. Instead, it proposes democratic, people-centred alternatives to globalization. The WSF is a response of the growing international movement that is challenging capitalist-led globalization and neo-liberal economic policies. Firmly committed to the belief that Another World Is Possible, the WSF is an open space for discussing alternatives to the dominant neo-liberal processes, for exchanging experiences and for strengthening alliances among mass organizations, people's movements and civil society organizations.

Compiled by Caroline Knowles 